\title{
A soKsZÍNŰ BIZALOM
}

\author{
KOVÁTS GERGELY
}

Budapesti Corvinus Egyetem

A tanulmány ${ }^{1}$ célja két kérdés megválaszolása. Az egyik kérdés, hogy miért lett az elmúlt évtizedekben a bizalom kutatása aktuális és népszerủ téma oly sok tudományterületen, és e sokszínüségből milyen dilemmák fakadnak. Ez alkalmat ad néhány olyan alapfogalom és összefüggés bemutatására, mint az intézményi és személyközi bizalom, vagy a bizalom, a bizalomraméltóság és a bizalom magatartási különbségének megkülönböztetése. A másik kérdés, hogy milyen kapcsolat van a bizalom és a kockázat, illetve a bizalom, a kontroll és az autonómia között. Mayer, Davis és Schoorman (1995) modellje, a megbízó-ügynök és a stewardship-elméletek alapján hogyan alkalmazhatóak ezek a személyközi és a szervezetközi viszonyokra?

Kulcsszavak: intézményi bizalom, személyközi bizalom, szervezetközi bizalom, autonómia, kontroll

The aim of the study is to answer two questions. The first question is why in recent decades, the search for trust has become a current and popular topic in so many disciplines, and what dilemmas come from this diversity. This provides an opportunity to present some basic concepts and relationships such as the distinction between institutional and interpersonal trust, or the distinction between trust, trustworthiness and the behavioural consequences of trust. The other question is the nature of relationship between trust and risk, and trust, control and autonomy. Based on the model by Mayer Davis $\mathcal{E}$ Schoorman (1995), the principal-agent and stewardship theories, how this can be applied to interpersonal and inter-organizational relationships?

Keywords: institutional trust, interpersonal trust, interorganizational trust, autonomy, control

\section{1 z $E_{d u c a t i o}{ }^{\odot}$ e száma a bizalom és az oktatás kapcsolatáról szól. A bizalom sokféle szituációban és társadalmi viszonyban érhető tetten, ami egyszer- re teszi a fogalmat átfogóvá és nehezen definiálhatóvá. A bizalom látható az}

Levelező szerző: Kováts Gergely, Corvinus Egyetem, 1093 Budapest, Fővám tér 8.

E-mail: gkovats1978@gmail.com

1 A cikk a Bolyai János Kutatási Ösztöndíj program keretében készült. Ezúton is szeretnék köszönetet mondani a Magyar Tudományos Akadémiának a támogatásért. 
állampolgárok oktatással kapcsolatos percepcióiban, a tanárok oktatási ágazathoz és annak irányítóihoz való viszonyában, a szülők és diákok döntéshozásba való bevonásában vagy kirekesztésében, az iskolai klímában, a diákok egymást támogató vagy épp hátráltató magatartásában, az iskola és az ágazat irányítási rendszerében, a kivándorlásban és még megannyi további témában. A bizalom jelentőségét az adja, hogy multiplikátor hatása van (Tóth 2009). Nemcsak a szereplők pozitív várakozását és együttműködési hajlandóságát (és ilyen módon az intézmények eredményességét) befolyásolja, hanem - önerősítő kört („angyali kört”; Győrffy 2014) létrehozva - önmagának az újratermelődésére is hatással van.

A bevezető tanulmány célja, hogy elméleti hátteret adjon a számban helyet kapó többi tanulmánynak. Ehhez két témakört szeretnék körbejárni. Egyfelől azt, hogy miért lett az elmúlt évtizedekben a bizalom kutatása aktuális és népszerủ téma oly sok tudományterületen, és e sokszínüségből milyen dilemmák fakadnak. Ez alkalmat ad néhány olyan alapfogalom és összefüggés bemutatására, amelyek részletes kifejtésére a szám további tanulmányaiban nem volt mód.

Másfelől szeretném röviden megvizsgálni egy konkrét bizalommodellen keresztül az autonómia, a kontroll és a bizalom összefüggését és ennek néhány olyan vonatkozását, ami releváns lehet az oktatási ágazat szempontjából.

\section{Mért érdekes téma a bizalom?}

A bizalom társadalmi szerepéről már olyan filozófusok, politikai gondolkodók és társadalomtudósok is írtak, mint Hobbes, Locke, Simmel, Durkheim vagy Parsons. A bizalommal való foglalkozás tehát régre nyúlik vissza. Mégis, a bizalom szerepével az 1980-as évektől újult erővel kezdtek el foglalkozni olyan társadalomfilozófusok, mint például Luhmann és Giddens, és később Putnam, Hardin vagy Fukuyama (1996). A különböző társadalomtudományok (így a szociológia és a szociálpszichológia) empirikus vizsgálataiban ugyan már az 1950-es és 1960-as években megjelent a bizalom fogalma, nagyobb figyelmet mégis csak az 1980-as és 1990-es években kapott e fogalom. Ekkor fedezte fel magának a közgazdaságtudomány és a szervezetkutatás, a politikatudomány és a szociológia, továbbá a közpolitika és közmenedzsment, a jog, a kriminalisztika és a pszichológia, valamint ezek egyes leágazása is, így az iskola- és oktatáskutatás is.

Jól szemlélteti ezt a folyamatot Tara Ebert 2009-es cikke, amelyben megvizsgálja a magas minőségü folyóiratokban a bizalommal kapcsolatban megjelent publikációk számának alakulását 1966 és 2005 között. A cikkek száma 1992-ig évi 10 alatt maradt, ezt követően a számok kisebb megszakításokkal folyamatosan nőttek: 1995-ben már körülbelül 20, 2000-ben 60 cikk jelent meg, 2003-ban pedig már 109 (Ebert 2009: 72). A cikkek $72 \%$-a az emberierőforrás-menedzsmenttel, a marketinggel, a stratégiával és pszichológiával foglalkozó folyóiratokban jelent meg, ezeken a területeken vált tehát leginkább népszerüvé a téma. Ugyanakkor bizalommal foglalkozó írások jelentek meg szociológiával, kommunikációval, közgazdaságtannal és közmenedzsmenttel foglalkozó folyóiratokban is.

Látható tehát, hogy sokféle tudományterületet mozgatott meg a bizalom előtérbe kerülése, amiből óhatatlanul adódik a kérdés: vajon mi az oka annak, hogy a jelenség tanulmányozása az utóbbi évtizedekben ennyire népszerű lett? 
A bizalom felértékelődése értelmezhető a tudomány expanziójának és a társadalomtudományok episztemológiai fordulatának következményeként. Ennél érdekesebbek azok a magyarázatok, amelyek a társadalom müködésének változására vezetik vissza a téma felértékelődését. Hardin (2006) szemléletesen állítja kontrasztba a kölcsönös függőségekkel átszőtt világunkat Bodo, a néhány évszázaddal korábban élt francia falusi, egyszerü élethelyzetével. Az ő normakövető viselkedését és magatartását a falusi kisközösség - szükség esetén - ki tudta kényszeríteni. Ma azonban a növekvő társadalmi munkamegosztás, a hálózatosodás, a technológiai fejlődés és a globalizáció mind a társadalom komplexitásának és a környezet bizonytalanságának növekedésével járnak, ami miatt egyre gyakrabban vagyunk kénytelenek ügyeinket olyanokra bízni, akiket személyesen nem ismerünk, vagy akiknek szakértelme az adott területen meghaladja a miénket. Egyre gyakrabban folytatunk interakciót ismeretlenekkel, és egyre többször kerülünk magunk is ismeretlen környezetbe (utazás, turizmus, migráció) (Sztompka 2003; Hardin 2006). Ez egyfelől felértékeli a hitelesítők, a garanciát és biztosítékot nyújtó szereplők helyzetét. Példaként gondoljunk arra, hogy hogyan kapcsolódott össze a felsőoktatás expanziója az akkreditációs ügynökségek megjelenésével. Másfelől azonban a bizalom szerepe is felértékelődik, mert a bizalom csökkenti a társas helyzetek kognitív komplexitását azáltal, hogy leszükíti azoknak a magatartásoknak a körét, amelyeket a többi szereplővel kapcsolatban valószínűnek tartunk. Bizalom nélkül mindig minden lehetséges magatartást figyelembe kellene venni, amely komplex környezetben lassabb döntéshozatalhoz, cselekvésképtelenséghez vezethet. Mindezek mellett a bizalom hozzájárul a közösségek kialakulásához és növeli a szereplök együttmüködési készségét is.

A fenti társadalmi változások együtt járnak a munka jellegének változásával is (Tyler 2016). A koordinált együttműködés többféle eszközzel is megteremthető. A szabályozás, az autoritás és a megfelelési kényszerek erősítése, a jutalmazás és büntetés alapvetően reaktív magatartást eredményez. A bizalom ugyanakkor - amellett, hogy lehetővé teszi a közösség céljaihoz való hozzájárulás érzésének megélését - rugalmas, a helyzethez igazodó proaktív magatartást, autonóm cselekvést tesz lehetővé. Tyler (2016) a bírókat hozza fel példaként, akik - ha döntéseiket egyre növekvő számú szabály korlátozza - nem tudnak minden tényezőt megfelelően figyelembe venni az ítélethozatal során. Bizalom esetén azonban olyan tényezők figyelembevételére is mód nyílik, amely a szabályokhoz kötött keretben nem volt lehetséges. A bizalomalapú kapcsolatok tehát rugalmasabbak, jobban tudnak igazodni a környezeti változásokhoz, mint a szabályokra vagy a nehezebben változtatható értékekre épülő kapcsolatok, mert a bizalom szabályok vagy értékek vak követése helyett a másik érdekeinek figyelembevételét teszi szükségessé.

Hardin (2006) egy másik tényezőt is kiemel, amely a bizalom kérdését fontossá teszi. A társadalmakban egyre több olyan komplex probléma merül fel (a munkanélküliség, a terrorizmus, a migráció, az infotechnológiai változások), amelyre a kormányzatok nem tudnak egyszerű közpolitikai választ adni. Márpedig a kormányzatokkal szembeni bizalom jelentős hatással lehet a közpolitikák kialakítására, implementációjára és eredményességére is (Boda 2016).

A bizalom tehát látszólag csodaszer, hiszen sokféle társadalmi bajra nyújt gyógyírt. A bizalommal foglalkozó írások gyakran azt sugallják (tudatosan vagy nem), hogy a bizalom minél magasabb foka a kívánatos. Ez a sugalmazás arra épül, hogy az alacsony szintü bizalom drágává teszi a szereplők közötti tranzakciókat, mert a szereplők a bizalom alacsony szintje miatt túlbiztosítják a kockázatokat, hosszabban ellenőrzik egymást, és 
a kelleténél több biztosítékot építenek be. Következésképp a magas szintű bizalom az ilyen költségek csökkenésével jár, ami kívánatos. Ennek ellenére a bizalom szerepét nem szabad túlértékelni, hiszen a korlátlan bizalom aligha lehet célszerü magatartás (Meg szabad-e bízni a rablóban?), és a bizalmatlanság is lehet kívánatos. A demokráciában működő fékek és ellensúlyok rendszere vagy a tudomány „szervezett szkepticizmusa” a bizalmatlanság bizonyos fokú intézményesülését jelenti.

Nem szabad figyelmen kívül hagyni a téma hazai aktualitását sem. Magyarországon és az egész posztszocialista térségben - azért tekinthető a bizalom különösen fontosnak, mert a rendszerváltás előtti korszak a paternalizmusra és a bizalmatlanságra épült, azaz arra, hogy az állam jobban tudja, hogy mire van szüksége az állampolgároknak, mint maguk az állampolgárok. Ez kiegészült a szabályok kijátszásának elfogadottságával. Mindez olyan torz értékrendet eredményezett, amely részben vagy egészben a rendszerváltás utáni időszakra is átörökítődött. Győrffy például megállapítja, hogy „a szocialista rendszer örökségeként továbbélő paternalizmus és jogszabály-kerülő magatartás ahelyett, hogy fokozatosan csökkent volna, több szempontból is inkább felerősödött" (Győrffy 2014: 100). Tóth hasonló eredményre jut a Bizalombiány, normazavarok, igazságtalanságérzet és paternalizmus a magyar társadalom értékszerkezetében címü tanulmányában (Tóth 2009), amelyet a későbbiekben is megerősített (Tóth 2018).

\section{A bizalom fogalmi sokszínüségének okai}

A bizalom témakörével sokféle tudományterület és ágazat foglalkozik. Ennek egyik következménye, hogy a kutatók körében nincs egyértelmű konszenzus a fogalom definíciójával kapcsolatban. McEvily és szerzőtársai például kijelentik, hogy „bár a szakirodalom jelentős elméleti és koncepcionális haladást ért el, a szakirodalom összességében nem jól integrált és hiányzik belőle a koherencia" (McEvily-Perrone-Zaheer 2003: 91). Ez persze nem egyedülálló: hasonló sokszínűség jellemzi például az attitüdökre, a normákra vagy a motivációra vonatkozó szakirodalmat is.

Ez a sokszínüség tükröződik például Hamm és munkatársai tanulmányában (Hamm et al. 2016), amely a közigazgatás (ebbe beleértik a kormányzatot is), a rendvédelem, a bíróságok és az orvoslás/egészségügy területén vizsgálja a bizalommal foglalkozó írásokat, és összehasonlítja az azokban megjelenő bizalom értelmezését, koncepcióját. (Lásd még Blomqvist 1997.) Egyik fontos megállapításuk, hogy a bizalom tartalma, értelmezése kontextusról kontextusra változik. Bár vannak olyan elemek, amelyek több kontextusban is megtalálhatóak, nincs egy olyan egységes fogalom, ami minden helyzetben közös értelmezés lenne. A kontextushoz igazodó rugalmasság egyfelől biztosítja azt, hogy a bizalom fogalmát sokféle közegben lehessen használni, ugyanakkor hozzájárul a definiálás nehézségéhez.

Az alábbi táblázat azt mutatja, hogy melyek voltak az egyes diszciplínákban a fogalom konceptualizálásához használt kulcskifejezések, és milyen tényezőkkel írták le a bizalmat befolyásoló (annak megelőlegezéséhez vezető) tényezőket, illetve milyen magatartásban látták a bizalom meglétének következményeit.

A fogalmi bizonytalanságot növeli az is, hogy különböző kontextusokban a bizalomnak többféle szinonimáját is használják, amelyekkel ezért az összemosódik. Sok szerző ezért látja fontosnak, hogy a bizalom fogalmát elhatárolja olyan kifejezésektől, mint az együttmüködés, a megbízhatóság (reliability), az előrejelezhetőség, a legitimitás, a hit, 
1. táblázat: A bizalom értelmezése négy területen (Forrás: Hamm et al. 2016: 147 felhasználásával)

\begin{tabular}{|c|c|c|c|}
\hline & $\begin{array}{l}\text { Koncepciót jellemző } \\
\text { kulcskifejezések }\end{array}$ & $\begin{array}{l}\text { Bizalmat befolyásoló } \\
\text { tényezők (antecendents) }\end{array}$ & Főbb következmények \\
\hline $\begin{array}{l}\text { Közigazgatás/ } \\
\text { Kormányzat }\end{array}$ & $\begin{array}{l}\text { konfidencia } \\
\text { hit } \\
\text { értékelés } \\
\text { várakozások } \\
\text { érdekek } \\
\text { sebezhetőség } \\
\text { érdekképviselet } \\
\text { (Fiduciary interest) }\end{array}$ & $\begin{array}{l}\text { teljesítmény* } \\
\text { intézmény kialakítása } \\
\text { (institutional design) }^{* \star} \\
\text { közhivatalt viselökkel } \\
\text { kapcsolatos tényezők } \\
\text { környezeti tényezők } \\
\text { bizalmat adóval kapcsolatos } \\
\text { tényezők }\end{array}$ & $\begin{array}{l}\text { együttműködés } \\
\text { szabálykövetés } \\
\text { elégedettség }\end{array}$ \\
\hline Rendőrség & $\begin{array}{l}\text { legitimitás } \\
\text { személyközi bizalom } \\
\text { konfidencia } \\
\text { eredményesség } \\
\text { hatékonyság } \\
\text { motiváció } \\
\text { karakter }\end{array}$ & $\begin{array}{l}\text { eredményesség* } \\
\text { az eljárások igazságossága } \\
\text { (procedural justice) } \\
\text { a működési terület jellemzői } \\
\text { (neighborhood factors) }^{* * *}\end{array}$ & $\begin{array}{l}\text { szabálykövetés } \\
\text { együttműködés }\end{array}$ \\
\hline Bíróságok & $\begin{array}{l}\text { érdekképviselet } \\
\text { (Fiduciary interest) } \\
\text { kötelezettségek } \\
\text { konfidencia } \\
\text { támogatás } \\
\text { jóváhagyás } \\
\text { legitimitás } \\
\text { elégedettség }\end{array}$ & $\begin{array}{l}\text { Igazságosság (fairness)* } \\
\text { teljesítmény } \\
\text { bizalmat adóval kapcsolatos } \\
\text { tényezők }\end{array}$ & $\begin{array}{l}\text { együttműködés } \\
\text { szabálykövetés }\end{array}$ \\
\hline Orvoslás & $\begin{array}{l}\text { konfidencia } \\
\text { sebezhetőség } \\
\text { hüség } \\
\text { kompetencia } \\
\text { becsületesség } \\
\text { bizalmasság }\end{array}$ & $\begin{array}{l}\text { bizalmat adóval kapcsolatos } \\
\text { tényezök* } \\
\text { érdemmel kapcsolatos } \\
\text { bizalom (merit trust) }\end{array}$ & $\begin{array}{l}\text { szabálykövetés } \\
\text { elégedettség } \\
\text { új technológiák } \\
\text { támogatása }\end{array}$ \\
\hline
\end{tabular}

*A szakirodalomban a legfontosabbnak tekintett befolyásoló tényező.

${ }^{* *}$ Például, hogy mekkora az állampolgárok bevonása, részvétele.

*** Például ha a terület hátrányosabb helyzetü, akkor ott alacsonyabb a rendőrséggel szembeni bizalom.

a konfidencia vagy a reputáció (ld. pl. Blomqvist 1997; Mayer-Davis-Schoorman 1995; Hardin 2006; Schoorman-Wood-Breuer 2015).

A koncepcionális különbségeken túl a nyelvi-kulturális különbözőségek is nehezítik az egységes fogalomhasználatot. Míg például az angolban némileg eltérő értelemben használják a trust és confidence szót (ámbár maguk a szerzők is vitatkoznak a pontos elhatárolásról), magyarul (továbbá az oroszban és a neolatin nyelvekben) mindkettőt bizalomnak fordítjuk (Cole-Cohn 2016). 


\section{A bizalom megragadása és néhány koncepcionális dilemma}

Lisa PytlikZillig és Christopher Kimbrough (egy szociálpszichológus és egy jogász) a bizalom definíciójáról szóló áttekintő tanulmányukban (2016) igyekeznek azonosítani azokat a területeket, amelyekben többé-kevésbé konszenzus van, és azokat, ahol értelmezési dilemmák, véleménykülönbségek találhatóak.

A tanulmány szerint a leginkább elfogadott (leggyakrabban idézett) definíció Rousseau és munkatársainak írásában található, és a következőképpen szól: „a bizalom olyan pszichológiai állapot, amelyben hajlandóak vagyunk elfogadni a sebezhetőséget mások szándékaival vagy magatartásaival kapcsolatos pozitív várakozások alapján." (Rousseau et al. 1998: 395.)

E definíciónak több fontos eleme is van: egyrészt a bizalom nem az egyén, hanem a kapcsolat jellemzője, azaz a bizalomra nem egy szereplő attitüdjeként kell tekinteni (miként az sokáig jellemző volt), hanem a két szereplő közötti viszony jellemzőjeként. Másrészt feltételezi, hogy a bizalmat adónak van valamilyen célja, aminek nem teljesülése sérelmet okoz számára. A cél teljesülése igényli a bizalmat kapó fél közremüködését. Aki bizalommal van, az úgy véli, hogy a bizalmat kapó fél megfelel majd ezeknek az elvárásoknak, és nem fog visszaélni a helyzettel, nem fogja azt opportunista módon kihasználni. Ebben persze nem lehet biztos, így a bizalom szoros kapcsolatban áll a kockázatvállalási hajlandósággal. Cél nélkül nem lehet bizalomról beszélni. Harmadrészt a bizalom konkrét ügyek vonatkozásában vizsgálható: elképzelhető, hogy valamivel kapcsolatban megbízok egy másik személyben, de más ügyben nem. Végül további fontos feltételezés, hogy a bizalom nem kikényszeríthető, annak autonóm döntés eredményének kell lennie, belülről fakad. $^{2}$

Alapesetben a bizalom két személy közötti kapcsolat jellemzője. Megkülönböztethetjük viszont a partikuláris és az általánosított (univerzális) bizalmat: míg az előbbi a két személy közötti személyes ismertségen és tapasztalaton alapuló bizalmat jelenti, addig az utóbbi inkább a társadalmi jellemzők, hovatartozás alapján meglévő bizalmat, amelyhez nincs szükség előzetes tapasztalatokra, személyes kapcsolatra. Jellemző például, hogy nagyobb bizalommal vagyunk azokkal kapcsolatban, akik hozzánk hasonlóak: például azonos nemzetiségüek, vallásúak, azonos helyről származnak vagy azonos iskolát végeztek - függően attól, hogy minek van jelentősége az adott kontextusban. Az általánosított bizalom tehát arra vonatkozó feltételezés (várakozás), hogy egy adott közösség bármely tagja egy szituációban adott módon, egymáshoz hasonlóan fog viselkedni (Tóth 2009). Mindehhez nincs szükség személyes kapcsolatra, elég, ha ennek a jellemzőnek a tudatában vagyunk.

Az általánosított bizalomhoz kapcsolódó további fogalom a bizalom rádiusza, ami azt mutatja meg, hogy az általánosított bizalom mennyire terjeszthető ki: vajon csak bizonyos szűkebb csoportok (szervezetek) tagjaiban bízunk vagy a társadalom egészében, bármely tagjában is? (Fukuyama 1996.)

A társadalom működése szempontjából gyakran nem a partikuláris, hanem az általánosított bizalom szintjét tartják a fontosabbnak, mert a modern társadalmakban gyak-

\footnotetext{
Ennélfogva ez a megközelítés nem ért egyet sem a kalkulatív bizalom koncepciójával (calculative based trust), sem az elrettentésalapú bizalommal (deterrence based trust). Mindkét esetben megkérdőjelezhető ugyanis, hogy lehet-e autonóm cselekvésről beszélni.
} 
rabban kell idegenekkel együttműködni. A bizalom szintjének és a bizalom rádiuszának megkülönböztetése révén azonban árnyaltabb képet kaphatunk egy társadalomban lévő bizalommal kapcsolatban: vannak országok, ahol a magas szintű bizalom magas rádiusszal érvényes (jellemzően olyan protestáns országok, mint például Svédország), más országokban viszont a magas szintű bizalom rádiusza szűk (pl. konfuciánus országok). A közép-kelet-európai országokban az általánosított bizalom szintje alacsonyabb, bár a rádiusz lehet nagyobb (pl. Lengyelország) és alacsonyabb is (pl. Románia) (Delhey-Newton-Welzel 2011).

A partikuláris és az általánosított bizalom alapvetően a személyek közötti (interperszonális) bizalmat ragadja meg. A bizalom azonban nemcsak a személyekkel kapcsolatban írható le, hanem beszélhetünk a szervezetekkel, az intézményekkel szembeni bizalomról is. A bizalommal foglalkozók véleménye megoszlik arról, hogy a személyközi és intézményi bizalom azonos mechanizmusok szerint müködik-e. Egyesek úgy vélik, hogy az emberek az intézményeket is antropomorfizálják, és az intézményekbe vetett bizalomról azonos módon döntünk, mint az emberekbe vetett bizalomról, ami miatt nem szükséges a merev különbségtétel a bizalom tárgyában. Mások úgy érvelnek, hogy az intézményekkel kapcsolatos bizalom személyes tapasztaláson nyugszik, „s ez a tapasztalás vetül ki azután különböző mechanizmusok révén tágabb kapcsolati kontextusokra" (Gelei 2014: 85). Megint mások szerint viszont az intézményi bizalom jellegében különbözik az interperszonális bizalomtól. Hardin (2006) például úgy érvel, hogy a kapcsolatok fontos jellemzője a személyesség, az interaktivitás, amely azonban nem áll fenn a távoli intézmények vonatkozásában (pl. kormányzat, bíróság, közoktatás), amelyekkel gyakran nincsen személyes kapcsolatunk, tapasztalatunk, legfeljebb hallomásaink. Ezért szerinte ezekben az esetekben helyesebb lenne egy másik fogalom, a confidence („megbízhatóság”) használata. Hasonlóan érvelnek Schoorman és munkatársai is (Schoorman-Wood-Breuer 2015), akik szerint ilyen intézmények esetében nincsen szó kapcsolatról, és nem értelmezhető sem a sebezhetőségre való hajlandóság, sem pedig a döntési kényszer (ezek a bizalom lényeges összetevői - lásd később). Helyesebb ezért az ilyen intézmények legitimitását vizsgálni, ami legfeljebb az intézmények kezdeti bizalomraméltóságának megítélésében játszhat szerepet, de nem azonos magával a bizalommal. Az intézményekkel kapcsolatos bizalom megléte vagy hiánya sokszor nem magával az intézménnyel való interakción alapszik, hanem a „szájreklámon”, az intézményről szóló, másokkal folytatott eszmecserén.

A személyközi és az intézményi bizalom vizsgálatát nehézzé teszi, hogy egyes esetekben a két megközelítés átfedésben van egymással. Például egyes személyek egy-egy intézmény képviselőiként jelennek meg, így a velük kapcsolatos bizalom tanulmányozható személyes és intézményi oldalról is. Egy egyetem kancellárjával kapcsolatos bizalom egyszerre szólhat a kancellárral mint személlyel és a kancellári rendszerrel mint intézménnyel kapcsolatos bizalomról. Amikor pedig egy szervezettel kapcsolatos bizalomról beszélünk, akkor ez jelentheti az adott szervezet tagjaival kapcsolatos általánosított bizalmat, és a szervezettel mint intézménnyel kapcsolatos bizalmat is.

Míg a menedzsment- és szervezetkutatások nagy része a személyközi viszonyokból kiindulva vizsgálja a bizalom természetét, addig a politikatudományban, a közpolitika-kutatásban és a jogban érvényesnek tartják az intézményekkel kapcsolatos bizalom vizsgálatát (Schoorman-Wood-Breuer 2015). Így például bevett gyakorlat a kormányokkal szembeni bizalom mérése és közreadása. 
Nemcsak a bizalom „tárgyával” kapcsolatos kérdések feszegethetőek, hanem a bizalom alanyával kapcsolatos kérdések is. Lehetséges-e, hogy nemcsak egy személy valakibe vagy valamibe vetett bizalmát vizsgáljuk, hanem például egy szervezet más szervezetekkel kapcsolatos bizalmát is? Hogyan lehetséges ezt koncepcionálisan értelmezni és megragadhatóvá tenni, mérni? Herian és Neal (2016) minden esetben szükségesnek látja annak tisztázását, hogy a bizalom vizsgálata milyen típusú szereplőkre irányul. Alapvetően kilenc lehetőséget különböztetnek meg attól függően, hogy a bizalmat kapó és adó típusa személy, csoport vagy intézmény. Véleményük szerint a bizalom természete, megragadhatósága (és ezért mérési módszerei) az egyes esetekben különböznek. Ezzel szemben úgy látják, hogy a kutatások többsége a személyközi bizalomra irányul, amelyeket utána más szintekre értelmeznek át. A mérések így gyakran koncepcionálisan bizonytalanok.

Polémia van azzal kapcsolatban is, hogy mi tekinthető a bizalom ellentétének. Abban nincs vita, hogy a skála egyik végpontja a magas bizalom, de mi van a skála másik végén? Bizalmatlanság? Bizalomhiány? Alacsony bizalom? Lewicki, Brinsfiled, Schoorman és munkatársai szerint (Lewicki-Brinsfiled 2012; Schoorman-Mayer-Davis 2007; Schoorman-Wood-Breuer 2015) a bizalom ellentéte a bizalmatlanság. Lewicki és munkatársai szerint (Lewicki-McAllister-Bies 1998) viszont a bizalom és a bizalmatlanság két különböző tényező, miként például Herzberg motivációs modelljében is külön tényező az elégedettség (ellentéte az elégedettség hiánya) és az elégedetlenség (ellentéte az elégedetlenség hiánya). Ennek megfelelően elképzelhető olyan szituáció, amelyet egyszerre jellemez

- bizalomhiány és bizalmatlansághiány (pl. kezdődő kapcsolat);

- magas bizalom és alacsony bizalmatlanság (pl. egy jól múködő, produktív kapcsolat);

- alacsony bizalom és magas bizalmatlanság (pl. egy óvatos, gyanakvó kapcsolat); és

- magas bizalom és magas bizalmatlanság (ambivalens kapcsolatok, vagy esetleg olyan kapcsolatok, amelyekben korábban már történt bizalomsértés és annak javítási kísérlete is) (Lewicki-Brinsfiled 2012).

Megosztja a kutatókat az is, hogy szükséges-e a kölcsönösség (reciprocitás) a bizalomhoz, vagy az lehet egyoldalú is. Bár az elméletben feltételezik, hogy a bizalom interakcióban alakul, fejlődik, az empirikus vizsgálatok gyakran már nem dinamikusak, és gyakorta egyoldalúan ábrázolják a bizalmat: azt vizsgálják, hogy egy szereplő egy időpillanatban bízik-e egy másikban. A mindkét félre kiterjedő diadikus vizsgálatok ritkák (ellenpéldaként lásd pl. Gelei-Dobos 2016; Gelei-Dobos-Dudás 2018), és a vizsgálatok ritkán terjednek ki a kölcsönösségre vagy a kapcsolat dinamikájára (PytlikZilligKimbrough 2016; Schoorman-Wood-Breuer 2015).

\section{Bizalom, bizalomraméltóság és kockázat: egy népszerü analitikus modell}

Mint minden tudományos kérdésben, úgy a bizalommal kapcsolatban is gyakoriak a tipizálási kísérletek. Zucker (1986) szerint például beszélhetünk folyamatalapú, tulajdonságalapú és intézményalapú bizalomról. Lewicki és Bunker (1996) kalkulatív, tudásalapú és identifikáción alapuló bizalmat különböztet meg. McAlliseter (1995) az érzelmi (affektív) és az értelmi (kognitív) bizalom között tesz különbséget. Kramer (1999) szerint történe- 
ti, szerepalapú, szabályalapú és kategóriaalapú bizalom van, míg Rommel és Christaens (2009) kompetenciaalapú, folyamatalapú és identifikáción alapuló bizalmat különít el. Az egyes tipológiák gyakran az empirikus vizsgálatok modelljeiként is szolgálnak. Ezek sokszor a mérőeszközök sokszínüségét is eredményezik, amelyek az empirikus kutatásokat is gyakran összehasonlíthatatlanná teszik (McEvily-Tortoriello 2011).

A menedzsmenttudományokban viszonylag elterjedtnek tekinthető Mayer és társainak (Mayer-Davis-Schoorman 1995) analitikus modellje (1. ábra), amelyet röviden összefoglalok annak érdekében, hogy egyrészt mélyebb betekintést adjak a bizalommal foglalkozó elméleti modellekbe, másrészt hogy rávilágítsak egy olyan problémára - a bizalom és kontroll kapcsolatára -, amely a közszféra és az oktatás minden szintjén értelmezhető és releváns. A modellben a szerzők a bizalmat a sebezhetőség vállalásának hajlandóságával definiálják. Ettől a hajlandóságtól megkülönböztetik a tényleges kockázatvállalási magatartást, amelyet a bizalom következményének tekintenek. A magatartás konkrét formája függ a szituációtól, de ilyennek tekinthető például a másikkal való együttműködés, az érzékeny információk megosztása, a másik fél szakértelmére való hagyatkozás stb.

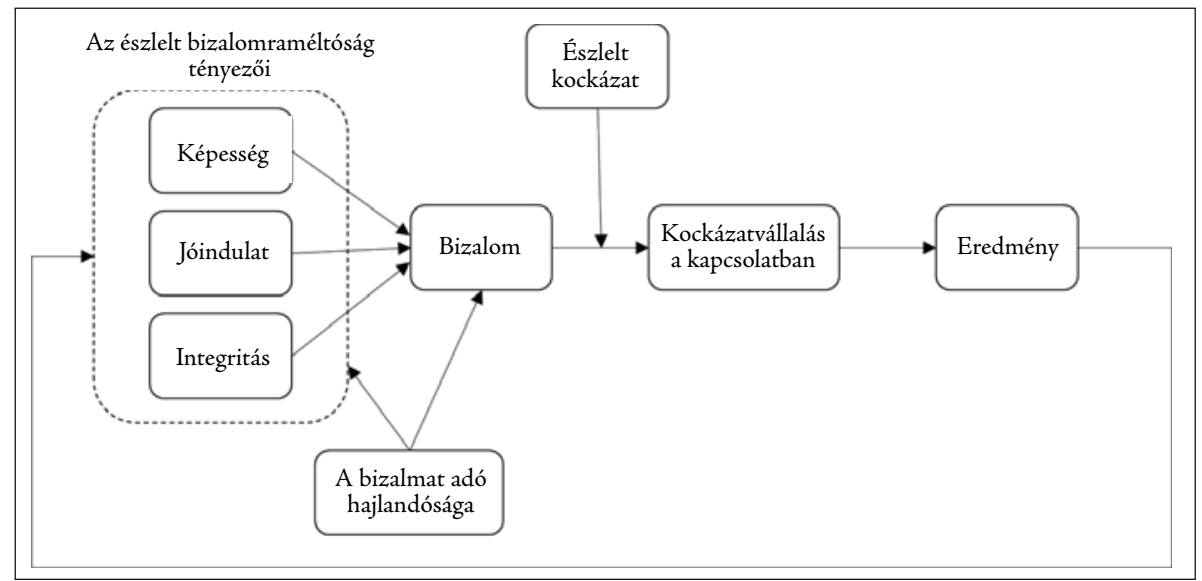

1. ábra: A bizalom modellje (Forrás: Mayer-Davis-Schoorman 1995)

A bizalomtól szintén elhatárolják a bizalmat „megelőlegező” tényezőket (antecendents), azaz azokat a tényezőket, amelyek befolyásolják a sebezhetőség vállalásának hajlandóságát. Ezek egyike a bizalmat adó általános beállítottsága/hajlama (propensity to trust), amely lényegében a korábban bemutatott általánosított bizalomnak feleltethető meg. A másik tényező a bizalmat kapó bizalomraméltósága (trustworthiness). Minél magasabb a bizalomraméltóság, annál nagyobb valószínűséggel vállalja a bizalmat adó a sebezhetőség kockázatát. A modell szerint a bizalomraméltóság függ

- a bizalmat kapó szereplő képességének megítélésétől, azaz attól, hogy az érintett a bizalmat adó szempontjából fontos tevékenységet várhatóan milyen szakértelemmel, hozzáértéssel végzi el;

- a bizalmat kapó szereplő jóindulatának megítélésétől, azaz hogy a bizalmat kapó a döntései során várhatóan milyen mértékben veszi figyelembe a bizalmat adó céljait, érdekeit; 
BIZALOM

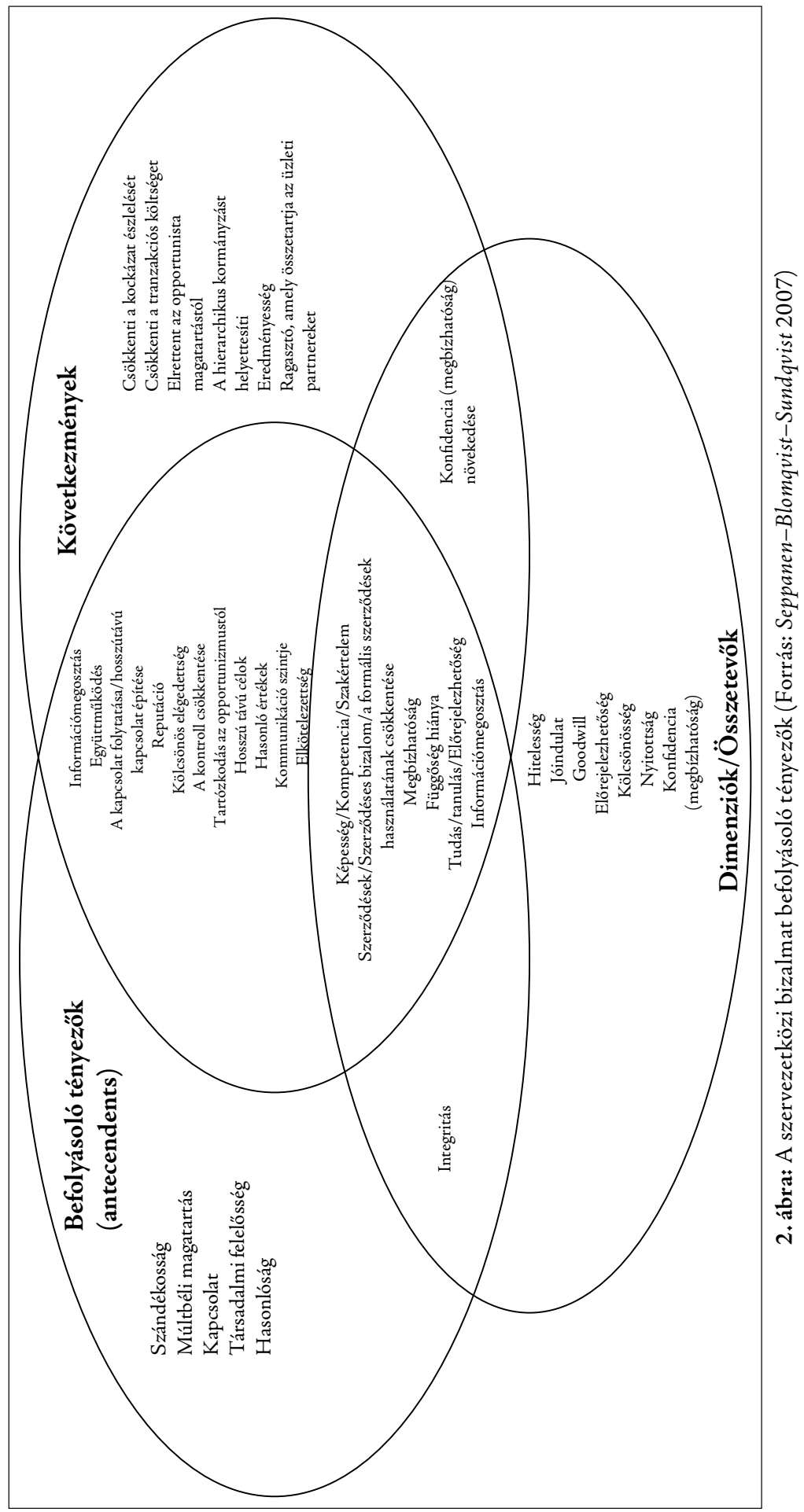


- a bizalmat kapó szereplő integritásának megítélésétől, azaz attól, hogy a bizalmat kapó értékrendje, normái mennyire elfogadhatóak a bizalmat adó számára.

A bizalomraméltóság tehát alapvetően függ attól, hogy a bizalmat adó fél hogyan észleli a bizalmat kapó felet. Az észlelés változhat a szituációtól függően és az idő múlásával is, ezért érdemes a szituatív tényezőket is figyelembe venni. Például Schoorman és munkatársai megjegyzik, hogy a képesség, jóindulat és integritás súlya nemzeti kultúránként, illetve pozícióként is változhat (Schoorman-Wood-Breuer 2015). Míg az Egyesült Államokban inkább a képességet helyezik előtérbe, addig Kínában inkább a jóindulatot. Hasonlóan: mást tart fontosabbnak egy vezető, mint egy beosztott a másik bizalomraméltóságának megítélése során. Érdemes megemlíteni, hogy több kutatás is megerősítette e bizalomraméltóságot alkotó tényezők egymástól való függetlenségét (SchoormanMayer-Davis 2007). Későbbi szerzők további szituatív tényezőkre mutattak rá, például a szereplők közötti hasonlóságra, amely megkönnyíti az egymással való azonosulást (ld. pl. Hurley 2012).

A szakirodalomban nagyon gyakori az a megközelítés, amely elkülöníti a bizalomraméltóságot befolyásoló tényezőket és a magatartási következményeket egymástól és magától a bizalomtól is. (Például a bizalom sokszínúségével foglalkozó részben bemutatott 1. táblázat is ezt a logikát tükrözi.) Nehézséget okoz azonban, hogy egyes tényezők egyidejüleg gyakran többféle kategóriába is sorolhatóak. Ezt támasztják alá Seppanen és munkatársai (Seppanen-Blomqvist-Sundqvist 2007), akik a szervezetközi bizalommal kapcsolatos szakirodalomban szereplő tényezőket összesítették (2. ábra). Az ábrán jól látszik, hogy például az információ megosztása egyaránt lehet csoportosítási szempont, a bizalomraméltóságot befolyásoló (azt megelőlegező) tényező és a bizalom következménye.

Mayer és munkatársai modelljében (Mayer-Davis-Schoorman 1995) a bizalom (sebezhetőségvállalási hajlandóság) és az észlelt kockázat összevetése határozza meg azt, hogy a bizalmat adó milyen valószínűséggel vállalja a kockázattal járó cselekvést, amely lényegében a bizalomdöntés eredménye. Ha a bizalom szintje magasabb, mint az észlelt kockázat, akkor a döntés vállalható. Ha viszont az észlelt kockázat szintje a magasabb, akkor szükség lehet a kockázatokat csökkentő intézkedésekre, például monitoring rendszerek kiépítésére. Ezek azonban nem a bizalmat növelik, hanem a kockázat mértékét csökkentik (erről részletesebben kicsit később).

Végezetül a másik fél magatartásának függvényében alakuló eredmény visszacsatolódik, és ennek fényében újra lehet értékelni a másik fél képességeit, jószándékát és integritását. Mindez logikus módon képezi le a bizalom kialakulásának és a bizalomvesztésnek a dinamikáját. Egy kapcsolat kezdetén a másik félről kevés információ áll rendelkezésre, így a bizalomraméltóságát közvetett információk alapján lehet megítélni (a képességeit például a végzettsége alapján), amit jelentősen befolyásolhat az általánosított bizalmunk. Ez nyilván alacsonyabb bizalmat és így alacsonyabb kockázatvállalási hajlandóságot eredményez. A sikeres együttmunkálkodás eredményeképpen egyre több információ áll rendelkezésre a másik jóindulatáról és értékrendjéről is, ami a bizalom megerősödését (vagy éppen csökkenését) eredményezi.

Noha a bizalommal foglalkozó szakirodalomban megoszlanak a vélemények arról, hogy mi a bizalom és milyen tényezőktől függ, abban teljes az összhang, hogy a bizalom önerősítő vagy önmagát gyengítő lehet. Azaz a visszaigazolt bizalom a bizalom további 
erősödését eredményezheti, a bizalmatlanság megerősítése azonban tovább erősíti a bizalmatlanságot. A bizalom és bizalmatlanság aszimmetrikus voltában is nagy az egyetértés: a bizalmi helyzet könnyen lerombolható, ugyanakkor a bizalmatlan helyzetből csak jelentős erőfeszítéssel lehet bizalmi helyzetet létrehozni.

A Mayer-féle modell alapvetően személyközi viszonyok értelmezésére szolgál, de több kísérlet is történt az intézményi bizalomra való adaptációra is (lásd például CamposCastillo et al. 2016). Ennek során az egyik alapvető nehézséget a jószándékúság fogalmának intézményekre vonatkozó értelmezése és adatokkal való alátámasztása jelenti.

\section{Autonómia, bizalom és kontroll: az ügynökelmélettől a stewardship-elméletig}

A közszféra - és azon belül a közoktatás - működését, eredményességét nagymértékben határozza meg az, hogy a jelentős szakmai autonómiával bíró szakértők (orvosok, tanárok, rendőrök stb.) milyen mértékben működnek együtt és osztják meg az információkat egymással. A bizalommal kapcsolatos szakirodalom a bizalom egyik fontos következményének tekinti a kooperáció erősödését. Az imént bemutatott modell alapján akkor valószínübb az együttműködés a két autonóm fél között, ha a felek megbízhatósága nagyobb, mint a szituációban észlelt kockázat. Ellenkező esetben csak akkor lesz együttműködés, ha csökken a kockázat nagysága. Ezt különböző monitoring és ösztönző mechanizmusok alkalmazásával lehet elérni. Ezek azonban nem a bizalmat erősítik a felek között, hanem csak a kockázatot csökkentik jó esetben olyan szintre, amely mellett az együttműködés már lehetséges.

Mindebből az következik, hogy az együttmüködés egy szakértői szervezetben alapvetően két stratégia mentén erősíthető: ha olyan monitoring és ösztönző rendszereket építünk, amelyek csökkentik a kockázatokat, illetve olyanokat, amelyek növelik a szereplők megbízhatóságát (illetve annak megítélését).

Az első stratégia tiszta elméleti kifejtése a megbízó-ügynök elmélet, amely a megbízó és ügynök céljainak ellentétét, az információk aszimmetrikus eloszlását és - ebből fakadóan - az ügynök önérdekkövető, opportunista magatartását tételezi fel. Abból indul ki, hogy ha az ügynöknek lehetősége van kihasználni a kínálkozó alkalmat, akkor meg is fogja azt tenni - akár a megbízó kárára is. Az ügynök opportunista magatartását a megbízó különböző megfigyelési és ösztönzési rendszerek kiépítésével szoríthatja a kívánt szint alá. A konkrét eszközök megválasztása az egyes megoldások kiépítésének és üzemeltetésének direkt és tranzakciós költségétől függ. Davis és munkatársai szerint (Davis-Schoorman-Donaldson 1997: 42) az ügynökelmélet lényege a "sebezhetőségek kizárása" (unwillingness to be vulnerable). Az elmélet tehát alapvetően bizalmatlan alapállásból tekint a szituációkra, és a bizalmatlanság intézményesítéséhez járul hozzá.

A második stratégia inkább a stewardship-elmélet (magyarul talán gondnokelméletnek lehetne fordítani) talaján áll. Elutasítja az ügynökelmélet önérdekkövetésre és opportunista magatartásra vonatkozó feltevését. Abból indul ki, hogy a szereplők között nincs szükségszerüen érdekellentét. Úgy véli, hogy az emberek alapvetően törekednek a megbízó érdekében eljárni és gondoskodó módon viselkedni, a kollektív célok lehetnek fontosabbak az egyéni céloknál. Mindez összhangban van például a közszférában dolgozó emberek motivációs elméleteivel. Az elmélet szerint az egyéni és közösségi célok üt- 
közése esetén előnyben részesíthetőek a közösségi célok, ha valaki számára az együttmüködő magatartás nagyobb hasznossággal jár. Így a szereplők csak bizonyos körülmények között válnak teljesen önérdekkövetőkké (Davis-Schoorman-Donaldson 1997). Ez nem azt jelenti, hogy az ügynököket csak a közösségi / társadalmi célok vezérlik, de feltételezi, hogy bizonyos mértékig ez mindenkiben jelen van, és mindenki belülről motivált. A kérdés csak az, hogy a megbízó milyen mértékben támaszkodik erre.

$\mathrm{A} z$ empirikus vizsgálatok eredményei nem mutatják egyértelmüen azt, hogy a stewardship-elmélet alapján folytatott vezetés hatékonyabb vagy eredményesebb, mint az ügynökelmélet alapján folytatott (Davis-Schoorman-Donaldson 1997; Schilemann 2013). Bár Schilemann (2013) szerint a két elmélet nem zárja ki feltétlenül egymást, van Slyke (2006) pedig úgy érvel, hogy lehetséges, hogy egy kapcsolat a megbízó-ügynök alapokról idővel megbízó-steward alapokra helyeződjön összhangban a bizalom kialakulásával, én mégis úgy látom, hogy a bizalom és a kontroll egymással ellentétben álló koordinációs mechanizmusok, így a két elmélet egyidejü létezésében érvényesülnek korlátok. Ha ugyanis az együttműködést a kockázatok csökkentésével (azaz a kontroll erősítésével) és nem a bizalom növelésével érjük el, azzal nemcsak leértékelődik a bizalom jelentősége, de megnehezedik a bizalom kialakulása is. Ahogy Schoorman és munkatársai fogalmaznak: „ha nagyon erős kontrollrendszer müködik egy szervezetben, az meggátolja a bizalom kialakulását. Nemcsak kevés olyan szituáció lesz, amelyben észlelhető marad a kockázat, de a bizalomraméltó cselekvéseket a kontrollrendszernek és nem a bizalmat kapónak fogják tulajdonítani. Így a bizalmat kapó azon cselekvése, amelyet a jószándék vagy integritás vezetett, egyszerűen a kontrollrendszerre adott válaszként látszódik." (SchoormanMayer-Davis 2007: 346-347.)

Emiatt különösen fontos, hogy milyenek azok az eszközök, amelyek a bizalomépítést lehetővé teszik. Míg az ügynökelmélet alapvetően hierarchikus kapcsolatot, nagy hatalmi távolságot és külső motivációs eszközök használatát tételezi fel, addig a stewardshipelmélet a kis hatalmi távolságot, az egyenrangúbb kapcsolatot és a belső motivációt erősítő eszközöket (dicséret, tisztelet, elismerés) helyezi előtérbe, amiben nagyobb szerepet kap az ügynök / steward autonómiája, racionális önkorlátozásra való támaszkodása. Míg tehát az ügynökelmélet inkább az alacsonyabb rendű szükségletekre épít (pénz, biztonság), a stewardship-elmélet a magasabb rendű szükségleteket részesíti előnyben. Ez lehetővé teszi azt is, hogy az ügynök/steward ne távolodjon el a megbízó céljaitól. (Schillemans 2013; Davis-Schoorman-Donaldson 1997.)

A stewardship-elmélet szerint kiemelkedő szerepe van a kiválasztásnak, amelynek során inkább olyanokat érdemes elönyben részesíteni, akik közösségileg elkötelezettebbek, belülről motiváltak és együttműködésre hajlamosabbak (szemben az ambiciózus, célorientált és versengő szereplőkkel).

A steward belülről motivált, ezért nagy autonómiát kell hagyni számára a megvalósítás során. Ez nem zárja ki a rendszeres jelentéstételi kötelezettséget, de ez inkább esély az egyeztetésre és nem kontrollcélú beszámoltatás. Mivel komplex környezetben az igényeket, az elvárásokat nehéz előre definiálni, ezért nagyon fontos a megbízó és a steward közelsége, gyakori találkozása és egyeztetése a célok és elvárások közös megértése érdekében. Ez lényegében az információs aszimmetria szűkítését jelenti. Ez egyben az ellenőrzés lehetőségét is megteremti. A megbízóval való közeli munka mellett a peerek és a haszonélvezőknek szóló beszámolók, illetve tőlük érkező visszacsatolások jelentik az ellenőrzés fö elemeit. 
Az ösztönzők közül kiemelkedő szerepe van a nem pénzügyi ösztönzőknek: a társak elismerésének, a dicséretnek, a társadalmi megbecsültségnek, az építő jellegű visszacsatolásoknak, a bizalmat tükröző gesztusoknak (például érzékeny információk megosztása).

A kiválasztás szempontjai (pl. a jóindulat, a belülről motiváltság hangsúlyozása), a rendszeres egyeztetések igénye (a közelség), a másik fél megerősítése, a belső ösztönzők erősítése, a formális beszámoltatások fejlesztő jellegű használata mind olyan eszközök, amelyek a szereplők közötti bizalom erősítését célozzák.

\section{Bizalom, szervezeti autonómia és ágazati felügyelet}

Az autonómia, bizalom és kontroll dilemmái nemcsak a személyközi viszonyokban vizsgálhatóak, hanem a szervezetközi viszonyokban is, így például az ágazatirányításban. Ennek különösen fontos apropót ad a közszférában az ún. ügynökségek elterjedése. Ezek olyan félautonóm szervezetek, amelyek a kormányzattól „karnyújtásnyira” müködnek (lásd van Thiel 2012; Verhoest 2018). Ilyennek tekinthetőek például a szabályozó hatóságok (pl. NAV) és a szolgáltatást nyújtó szervezetek (pl. kórházak, tankerületek és iskolák, egyetemek), amelyek strukturálisan elkülönülnek a kormányzattól és a minisztériumoktól, önálló szervezeti határokkal rendelkeznek, és - az autonómiájuk fokától függően - önállóbb pénzügyi és személyzeti döntési szabadsággal rendelkeznek. Önállóságuk viszont korlátozott, mert a felügyeletüket a legtöbb esetben külső, kormányzati szereplők látják el (Verhoest 2012). A részben autonóm ügynökség és a felügyeletet ellátó szerv (minisztérium) közötti viszony tekinthető szervezetközi viszonynak, amelyben jól értelmezhető a bizalom kérdése is. Vajon mekkora egy iskola autonómiája és a felügyelete milyen eszközökkel valósul meg? Ezek megválasztásában milyen szerepet játszik az ügynökség és a minisztérium közötti bizalom?

A Mayer és munkatársai modelljéből (Mayer-Davis-Schoorman 1995) kiindulva az ügynökségnek ,adományozott” autonómia foka attól függ, hogy a minisztérium mennyire látja bizalomra méltónak az ügynökséget, és a müködésében mekkora kockázatot lát.

$\mathrm{A} z$ ügynökség bizalomraméltóságának észlelését az ügynökség aktív stratégiákkal alakíthatja (Rommel-Christaens 2009). Például építhet kapcsolatot parlamenti képviselőkkel, a döntéshozó szereplőknek proaktív módon személyre szabott információkat biztosíthat, igyekezhet aktív kapcsolatot ápolni a miniszter kabinetjével, kezdeményezhet demonstratív akciókat stb. Egy másik megközelítést jelenthet, ha más társszerveket igyekszik kedvezőtlen fényben feltüntetni annak érdekében, hogy a saját hozzáértését, megbízhatóságát erősítse.

A kockázatokat illetően a szervezet mérete és az általa lefedett terület politikai érzékenysége játszik szerepet. Annál erősebb a politikai szereplők kontrolligénye az ügynökség felett, minél nagyobb az ügynökség müködésének kockázata a minisztériumra nézve.

Mindezek miatt az ügynökség jogi és tényleges autonómiája között jelentős különbség lehet. Ez ugyanakkor nemcsak szükebb autonómiát, hanem - nagyobb bizalom esetén akár bővebb autonómiát is jelenthet, pl. amikor a minisztérium nem érvényesíti azokat a jogosítványokat, amelyek egyébként a rendelkezésére állnak (Verhoest-Rommel-Boon 2015). 


\section{Összefoglalás}

E rövid áttekintésnek nem lehetett célja a bizalom sokszínű és széttartó kutatási irodalmának teljes körű áttekintése. Ehelyett egyrészt a bizalom jelentőségének illusztrálására, másrészt néhány olyan alapfogalom és összefüggés bemutatására törekedtem, amelyet szélesebb körben is használnak, és így a szám többi cikkének háttereként szolgálhat. Ezek közé tartozik a bizalom, a bizalomraméltóság és a bizalom magatartási különbségének megkülönböztetése, az intézményi és személyközi/szervezetközi bizalom fogalma, a bizalom és a kockázat, illetve a bizalom, a kontroll és az autonómia egymással való kapcsolata.

A bizalom koncepciója minden társadalmi viszony értelmezéséhez felhasználható. Alkalmazható a személyek közötti viszonyok (például tanár-igazgató) értelmezésében éppúgy, mint a kollektív entitások közötti viszonyokra (például minisztérium-iskola). A bizalom (a sebezhetőség vállalásának hajlandósága) és a kockázat nagysága határozza meg azt, hogy a döntéshozó vállalja-e a bizalom megadásával (például az autonómia biztosításával) járó sebezhetőséget. A kontrolleszközökkel és biztosítékokkal csökkenthető az ezzel járó kockázat, de ez egyben a bizalom kialakulását is akadályozhatja, ami a kontrolleszközök további fenntartását teszi szükségessé. A bizalom kialakulása és fenntartása viszont önerősítő folyamat. Mindez jól párhuzamba állítható a megbízó-ügynök elmélettel és a stewardship-elmélettel is.

\section{IRODALOM}

Blompvist, K. (1997) The Many Faces of Trust. Scandinavian Journal of Management, Vol. 13. No. 3. pp. 271-286.

Boda Zs. (2016) Intézményi bizalom és a közpolitikák eredményessége. In: Boda Zs. (ed.) Bizalom és közpolitika. Jobban müködnek-e az intézmények, ba biznak bennük? Budapest, Argumentum - MTA TK Politikatudományi Intézet. pp. 7-22.

Campos-Castillo, C., Woodson, B. W., Theiss-Morse, E., Sacks, T., Fleig-Palmer, M. \& PeEK, M. E. (2016) Examining the Relationship between Interpersonal and Institutional Trust in Political and Health Care Contexts. In: E. Shockley, T. M. S. Neal, L. M. PytlikZillig \& B. Bornstein (eds) Interdisciplinary Perspectives on Trust - Towards Theoretical and Methodological Integration. New York, Springer. pp. 99-117.

Cole, L. M. \& Conn, E. S. (2016) Institutional Trust Across Cultures: Its Definitions, Conceptualizations, and Antecedents Across Eastern and Western European Nations. In: E. Shockley, T. M. S. NeAl, L. M. PythikZilligg \& B. Bornstein (eds) Interdisciplinary Perspectives on Trust - Towards Theoretical and Methodological Integration. New York, Springer. pp. 157-176.

Davis, J. H., Schoorman, F. D. \& Donaldson, L. (1997) Toward a Stewardship Theory of Management. The Academy of Management Review, Vol. 22. No. 1. pp. 20-47.

Delhey, J., Newton, K. \& Welzel, C. (2011) How General Is Trust in "Most People"? Solving the Radius of Trust Problem. American Sociological Review, Vol. 76. No. 5. pp. 786-807.

Ebert, T. (2009) Facets of Trust in Relationships - A Literature Synthesis of Highly Ranked Trust Articles. Journal of Business Market Management, Vol. 3. No. 1. pp. 65-84.

Funuyama, F. (1996) Trust: The Social Virtues and The Creation of Prosperity. New York, Free Press. 
Geler A. (2014) Az üzleti kapcsolatok irányítása - fókuszban a bizalom. Közgazdaság, Vol. 9. No. 2. pp. 85-99.

Gelei A. \& Doвos I. (2016) Bizalom az üzleti kapcsolatokban. A diadikus adatelemzés egy alkalmazása. Közgazdasági Szemle, Vol. 63. No. 3. pp. 330-349.

Gelei A., Doвos I. \& Dudás L. (2018) Bizalom és megbízhatóság - egy módosított ismételt bizalomjáték eredménye. Statisztikai Szemle, Vol. 96. No. 8-9. pp. 769-793.

GyőrfFy D. (2014) Bizalom és gazdaságpolitika: fejezetek az euró történetéből. MTA doktori értekezés.

Hamm, J. A., Lee, J., Trinkner, R., Wingrove, T., Leben, S. \& Breuer, C. (2016) On the Cross-Domain Scholarship of Trust in the Institutional Context. In: E. Shockley, T. M. S. Neal, L. M. PytlikZillig \& B. Bornstein (eds) Interdisciplinary Perspectives on Trust - Towards Theoretical and Methodological Integration. New York, Springer. pp. 131-156.

Hardin, R. (2006) Trust. Cambridge - Malden, Polity Press.

Herian, M. N. \& Neal, T. M. S. (2016) Trust as a Multilevel Phenomenon Across Contexts: Implications for Improved Interdisciplinarity in Trust Research. In: E. Shockley, T. M. S. Neal, L. M. PytlikZillig \& B. Bornstein (eds) Interdisciplinary Perspectives on Trust - Towards Theoretical and Methodological Integration. New York, Springer. pp. 117-130.

Hurley, R. F. (2012) The Decision to Trust: How Leaders Create High-Trust Organizations. San Francisco, Jossey-Bass.

Kramer, R. M. (1999) Trust and Distrust in Organizations: Emerging Perspectives, Enduring Questions. Annual Review of Psychology, Vol. 50. No. 1. pp. 569-598.

Lewicki, R. J. \& Brinsfiled, C. (2012) Measuring Trust Beliefs and Behaviours. In: F. Lyon, G. Möllering \& M. N. K. Saunders (eds) Handbook of Research Methods on Trust. Cheltenham (UK) and Northampton (USA), Edward Elgar. pp. 29-39.

Lewicki, R. \& Bunker, B. (1996) Developing and Maintaining Trust in Work Relationships. In: R. Kremer \& T. Tyler: Trust in Organizations: Frontiers of Theory and Research. Thousand Oaks (CA, US), Sage. pp. 114-139.

Lewicki, R. L., McAllister, D. J. \& Bies, R. J. (1998) Trust and Distrust: New Relationships and Realities. The Academy of Management Review, Vol. 23. No. 3. pp. 438-458.

Luhmann, N. (1982) Trust and Power. Chicester, John Wiley \& Sons Inc.

McAllister, D. J. (1995) Affect and Cognition-based Trust as Foundations for Interpersonal Cooperation in Organizations. The Academy of Management Journal, Vol. 38. No. 1. pp. 24-59.

McEvily, B., Perrone, V. \& Zaheer, A. (2003) Trust as an Organizing Principle. Organization Science, Vol. 14. No. 1. pp. 91-103.

McEvily, B. \& Tortoriello, M. (2011) Measuring Trust in Organisational Research: Review and Recommendations. Journal of Trust Research, Vol. 1. No. 1. pp. 23-63.

Mayer, R. C., Davis, J. H. \& Schoorman, F. D. (1995) An Integrative Model of Organizational Trust. The Academy of Management Review, Vol. 20. No. 3. pp. 709-734.

PytlikZillig, L. M. \& Kimbrough, K. D (2016) Consensus on Conceptualizations and Definitions of Trust: Are We There Yet? In: E. Shockley, T. M. S. Neal, L. M. PytlikZillig \& B. Bornstein (eds) Interdisciplinary Perspectives on Trust - Towards Theoretical and Methodological Integration. New York, Springer. pp. 17-46.

Rommel, J. \& Christanes, J. (2009): Steering from Ministers and Departments. Coping Strategies of Agencies in Flanders. Public Management Review, Vol. 11. No. 1. pp. 79100 . 
Rousseau, D. M., Sitkin, S. B., Burt, R. S. \& Camerer, C. (1998) Not So Different after All: A Cross-discipline View of Trust. The Academy of Management Review, Vol. 23. No. 3. pp. 393-404.

Schillemans, T. (2013) Moving Beyond the Clash of Interests: On Stewardship Theory and the Relationships between Central Government Dpartments and Public Agencies. Public Management Review, Vol. 15. No. 4. pp. 541-562.

Schoorman, F. D., Mayer, R. C. \& Davis, J. H. (2007) An Integrative Model of Organizational Trust: Past, Present, and Future. The Academy of Management Review, Vol. 32. No. 2. pp. 344-354.

Schoorman, F. D., Wood, M. M. \& Breuer, C. (2015) Would Trust by Any Other Name Smell as Sweet? Reflections on the Meanings and Uses of Trust Across Disciplines and Context. In: B. H. Bornstein \& A. J. Tomkins (eds) Motivating Cooperation and Compliance with Authority. Nebraska Symposium on Motivation. New York, Springer. pp. 13-36.

Seppanen, R., Blomqvist, K. \& Sundqvist, S. (2007) Measuring inter-Organizational Trust - A Critical Review of the Empirical Research in 1990-2003. Industrial Marketing Management, Vol. 36. No. 2. pp. 249-265.

Sztompka, P. (2003) Trust - A Sociological Theory Sztompka. Cambridge, Cambridge University Press.

Tóтн I. Gy. (2009) Bizalombiány, normazavarok, igazságtalanságérzet és paternalizmus a magyar társadalom értékszerkezetében. A Gazdasági felemelkedés társadalmi-kulturális feltételei címü kutatás zárójelentése. Budapest, Tárki.

Tóтн I. Gy. (2018) Turánbánya? Értékválasztások, beidegződések és az illiberalizmusra való fogadókészség Magyarországon. In: Jaкав A. \& Urbán L. (eds) Hegymenet. Társadalmi és politikaik kibivások Magyarországon. Budapest, Osiris Kiadó. p. 37-50.

Tyler, T. R. (2016) Trust in the Twenty-first Century. In: E. Shockley, T. M. S. Neal, L. M. PytlikZillig \& B. Bornstein (eds) Interdisciplinary Perspectives on Trust - Towards Theoretical and Methodological Integration. New York, Springer. pp. 203-215.

van SLYKe, D. M. (2006) Agents or Stewards: Using Theory to Understand the Government-Nonprofit Social Service Contracting Relationship. Journal of Public Administration Research and Theory, Vol. 17. No. 2. pp. 157-187.

van Thiel, S. (2012) Comparing Agencies across Countries. In: K. Verhoest, S. van Thiel, G. Bouckaert \& P. Legreid (eds) Government Agencies. Practices and Lessons from 30 Countries. Houndmills, Macmillan. pp. 18-26.

Verhoest, K. (2018) Agencification in Europe. In: E. Ongaro \& S. van Thiel (eds) The Palgrave Handbook of Public Administration and Management in Europe. Houndmills, Macmillan. pp. 327-346.

Verhoest, K., Rommel, J. \& Boon, J. (2015) How Organizational Reputation and Trust May Affect the Autonomy of Independent Regulators? The Case of Flemish Energy Regulator. In: A. WæraAs \& M. MaOr (eds) Organizational Reputation in the Public Sector. New York, Routledge. p. 118-138.

Zucker, L. G. (1986) Production of Trust: Institutional Sources of Economic Structure, 1840-1920. Research in Organizational Behavior, Vol. 8. No. 1. pp. 53-111. Idézi: Pytlik Zillig-Kimbrough 2016.

A cikk a Creative Commons Attribution 4.0 International License (https://creativecommons.org/licenses/ by/4.0/) feltételei szerint publikált Open Access közlemény, melynek szellemében a cikk bármilyen médiumban szabadon felhasználható, megosztható és újraközölhető, feltéve, hogy az eredeti szerző és a közlés helye, illetve a CC License linkje és az esetlegesen végrehajtott módosítások feltüntetésre kerülnek. (SID_1) 